\title{
NITROGEN CYCLING IN INDONESIAN AGRICULTURE AROUND 1968 TO 2008 AND ITS ENVIRONMENTAL IMPACTS
}

\author{
Tajuddin Bantacut ${ }^{\mathrm{a}}$, Julian Pradifta ${ }^{\mathrm{b}}$ \\ ${ }^{a}$ Department of Agroinduatrial Technology, Faculty of Agricultural Technology, Bogor Agricultural University \\ Dramaga Campus, PO BOX 220, Bogor 16002, West Java, Indonesia - bantacuttajuddin@ gmail.com \\ ${ }^{b}$ PT Bank Mandiri (Persero), Tbk. Verification Income RCC Cirebon - Surabaya Jl. Yos Sudarso No. 11, Cirebon \\ 45111, West Java Indonesia
}

\begin{abstract}
Government of Indonesia has been deciding a policy of agricultural development by means of intensification for more than four decades. This development brought about environmental pollution together with productivity improvement due to a massive use of fertiliser (mainly nitrogen) and pesticides. The objectives of this study were to examine the efficiency of nitrogen and its lost to the environment, to estimate its environmental impacts and their mitigation measures. Nitrogen mass-balance models were developed to determine production, efficiency and the nitrogen losses. The results showed the trend of the system, increased the lost and decreased the efficiency of nitrogen fertiliser around 1968 and 2008. The material balance model outputs predicted that around $140 \mathrm{~kg} N / \mathrm{ha} . y e a r$ in 2008 were lost and entering the environment or ecosystem. The future of Indonesian agriculture will be more intensive and fertiliser application will increase. Fertiliser impacts are decreased of nitrogen efficiency, soil organic matters, macro-elements and organisms, and groundwater contamination and air pollution. It is strongly recommended that the future of Indonesian agricultural development should sustain the production by optimising the input and cut the losses.
\end{abstract}

Keywords: agriculture intensification, agricultural pollution, environmental impacts, balance model, nitrogen cycle

(Diterima: 19-09-2017; Disetujui: 07-12-2017)

\section{Introduction}

Agricultural intensification is a policy taken by the Indonesian government to meet food needs in line with the growth of the population (Sudaryanto and Rusastra, 2006) as one of the efforts to increase agricultural output by optimising existing farmland (Adi, 2010; Edgerton, 2009; Shriar, 2000). It is a highly accepted method to increase agricultural production both quantity and quality (Tscharntke, et al., 2012), and differs from shifting cultivation which involves basic tools and techniques, low-level of inputs and subsistence level of production and consumption (Rasul and Thapa, 2003). The other way to meet food demand is to increase the area under production (Edgerton, 2009). Intensive agriculture is more acceptable than expansion of cropland for greenhouse gas emission and nitrogen use (Burney et al., 2010; Tilman et al., 2011).

Productivity of food crops in Indonesia is likely to increase every year. BPS (1991) reported that the average productivity of food crops in 1968 about 17.87 ton/ha, then increased in 2008 to about 41.37 ton/ha (BPS, 2010). This was partly caused by application of fertiliser together with pest control and plant management. Therefore, agricultural activity in 2008 was more intensified. Many factors influence the increase of agricultural productivity, among others are improved crop varieties, more advanced land preparation, increased application of (mineral) fertilisers and better post-harvest processing in addition to environmental factors such as water, temperature, light, atmosphere, nutrients, fire and grazer (Haferkamp, 1988). The current development of this method called the system of crop intensification (SCI) (Abraham et al., 2014), and System Rice Intensification (SRI) designed special for rice that is being developed in Indonesia (Suciati et al., 2014).

The main factor of productivity improvement was the increased use of nitrogen fertilisers. Productive agriculture needs a large amount of expensive nitrogenous fertilisers (Daubresse et al., 2010). It is one source of plant nutrients that determines the crops yield. Manipulation of nitrogen availability affects the plant productivity (Gough et al., 2000). In principle, a balanced fertilisation might be applied according to crop needs and naturally available nutrients in the soil (Gruhn et al., 2000), the sustainability of production systems and adequate profits for farmers. However, the trend is still increasing to meet higher yield in the future (Tilman et al., 2011). In the case of Indonesia, Bantacut (1992) found that fertiliser use increased in 1984 and 1988 which was about 245 to $301 \mathrm{~kg} / \mathrm{ha}$. The results of Agricultural Environmental Body survey in 2005 showed that the use 
of nitrogen fertiliser was at 300-600 kg/ha (Mulyadi and Sutrisno, 2007). It can be concluded that the trend was increasing in that period, and continue in recent and in the coming years.

Without good management of its application, introduction of large amounts of nitrogen into the environment has many undesirable impacts on water, terrestrial, and atmospheric resources (Ribaudo et al., 2011). Agricultural technology development based on intensification will evidently affect the environment so that it can disrupt the natural ecosystem. Nitrogen fertiliser is necessary for crop plants, especially at the beginning, but the higher use of nitrogen fertiliser will affect the surrounding ecosystem sustainability. Increasing fertiliser will result in land degradation, water pollution and, human and the environmental health (Hall and Robarge, 2004; Moller et al., 2008; Stoate et al., 2001), soil erosion and declining soil fertility, decrease in water availability from high use of water for irrigation, water quality deterioration through concentrations of nutrients and agrochemicals (Gregory et al., 2002), and soil biodiversity and agroecosystem function (Giller $e t$ al., 1997).

Fertiliser N-recovery efficiency by the first crop is 30 to $50 \%$ (Ladha et al., 2005). In the tropical environment, the efficiency of applied $\mathrm{N}$ is less than 50\% (Baligar and Bennett, 1986; Baligar et al., 2001), for upland crops about $40-60 \%$ and for flooded rice crops is only $20-40 \%$ (Vlek and Byrnes, 1986). $\mathrm{N}$ inputs exceed assimilation capacity will increase nitrogen losses rapidly (Schlegel et al., 1996). Reducing application rate reduces the losses of all forms of reactive nitrogen (Ribaudo et al., 2011). Therefore, it can be concluded that the main characteristic of intensive agriculture is the massive use of fertiliser which causes environmental pollution and problems. A great potential is available for increasing the efficiency of $\mathrm{N}$-uptake on this very responsive crop to help alleviate food deficits in the developing world.

This study examined the uptake efficiency of nitrogen fertiliser application (it is also known as nitrogen use efficiency/NUE) expressed simply as the yield of nitrogen per unit of available nitrogen in the soil (Lea and Azevedo, 2006), and its possible environmental changes between 1968 and 2008. The balance model was developed as a tool to estimate the nitrogen efficiency and cycle in the agricultural environment. This model links the input, output and nutrients discharged into the environment. The predicted output (nitrogen utilisation and lost) was used to estimate the level of the impact due to the loss of nitrogen to the environment. The results obtained from nitrogen balance model then used to develop a simple strategy of nitrogen management.

\section{Method}

\subsection{Data Collection}

Data used were fertiliser apllication level, productivity improvent, were collected from secondary sources, mainly research results (working papers, journal articles, and statistics) included nitrogen input, plant fixation, soil bacterial fixation, atmospheric precipitation and official data from governmental bodies. Rate of nitrogen uptake by plant and flow from one compartment to the others were approached by linear calculation based on available data. Main sources of data were Food Crops Research and Development Centre, Ministry of Agriculture, Ministry of Environment, Central Bureau of Statistics, and university libraries.

\subsection{System Approach}

Systems approach was used to find the critical factors and look for optimum solutions of the relevant issues using quantitative models that support decision-making. Agriculture is considered as a complex system that involves many factors and constraints associated with each other. Factors and constraints are environmental aspects. A comprehensive approach is needed to find the optimum solution of environmental aspects. Therefore, this system approach was used to analyse the environmental aspects of the farming system. Detailed explanation of each constraint can be seen in the model development of Section 3.

\subsection{Systems Identification}

A farming system may consist of four main compartments that include soil, plants, animals and fish pond. Plant includes crops product or parts of plants that can be consumed by animals and fish. Animal acts as consumer and produce nutrients that stored in meat, milk, and manure. Fish acts as consumer and produce nutrients stored in the fish. Soil consists of organic nutrient exchange and mineral components of soil.

\subsection{System Boundary}

Two models of simple and complex were developed. A simple model was developed with the assumption that the agro-ecosystem is a single compartment that connects the input (I), product (P) and loss (L). Although this simple model cannot determine specifically internal flow $\mathrm{I}, \mathrm{P}$, and $\mathrm{L}$, this system is usable to calculate the efficiency (Figure 1). The output of this model was used as a basis of comparison to a more complex model.

A complex model was built to describe the real situation of Indonesian agricultural systems. Assuming that agricultural practices do not change for the next few years and do not alter the physical and chemical properties of the soil or other environmental aspects that affect the condition of the farming systems. This model identifies the system and spliting compartment into subcompartments consisting of ten compartments. The 
relationship among the ten compartments were used to identify the boundaries of the system (Figure 2).

\subsection{Model Description}

A simple agroecosystems model describes the agricultural systems into input and output relationship. Detailing the simple model to the complex model was to improve the accuracy and get more suitable model to describe the real situation of agroecosystems in Indonesia. These models were developed to assess the agroecosystems production, efficiency and nitrogen lost to the environment. Nitrogen inputs will go into every compartment through internal flows of nitrogen that connect a compartment to another compartment.

\subsection{Nitrogen Balance}

Agricultural system was assumed as a closed system where all the nutrient flows take place within the system boundaries. The first step to make the nitrogen balance model was identification of the compartment. Then, set up the nitrogen balance equation to determine the nutrient inflow and outflow between compartments. The general equation of material balance is:

$$
\begin{gathered}
\text { Accumulation }=\text { inflow }- \text { outflow }+ \text { production }- \\
\text { consumption }
\end{gathered}
$$

In identifying the efficiency equation (ratio of variable values), due to the unavailability of quantitative data on product utilisation, some equations were assumed based on similarities using findings of previous studies. After identifying the mass balance and efficiency equations of nitrogen, the production, nutrient losses, and the efficiency can be determined.

\section{Nitrogen Balance Model}

\subsection{Nitrogen Input}

The agriculture situation in 2008 was different from 1968 in which green manure or organic fertiliser was commonly used, while the use of mineral fertilisers was very little. This difference can be seen from the use of nitrogen fertiliser. According to Bantacut (1992) about 10 $\mathrm{kg} \mathrm{N} / \mathrm{ha}$.year or 95,000 tons of nitrogen fertiliser was available in 1968. Based on BPS (2010), the average use of fertiliser in 2008 was about $160 \mathrm{~kg} \mathrm{~N} / \mathrm{ha}$.year or total of 4,345 thousand tons. The main users of fertiliser are food crops, mainly rice, corn, soybeans, peanuts, cassava, and sweet potatoes.

Legumes can fix nitrogen from the atmosphere around 80-90 kg N/ha.year. It can be estimated that the nitrogen fixation in 1968 was higher than in 2008, and it was about $40 \mathrm{~kg} \mathrm{~N} /$ ha.year in 1968 (Supriadi et al. 1986). Soemarsono (2008) estimated that plant N-fixation in 2008 was $25 \mathrm{~kg} \mathrm{~N} / \mathrm{ha}$.year. For soil bacterial fixation was about $20 \mathrm{~kg} \mathrm{~N} / \mathrm{ha}$.year and $10 \mathrm{~kg} \mathrm{~N} / \mathrm{ha}$.year in 1968 and 2008 respectively. Taslim et al. (1988) estimated atmospheric deposition in 1968 was about $4 \mathrm{~kg} \mathrm{~N} /$ ha.year and Soemarsono (2008) reported about $8 \mathrm{~kg} \mathrm{~N} /$ ha.year in 2008.

\subsection{The Simple Model}

The simple model assumed agricultural systems as a single compartment (Figure 1). Where the input (I) equal to the product $(\mathrm{P})$ plus losses $(\mathrm{L})$. In this model, the internal flows were not taken into account, but this system can calculate the efficiency of the system (E).

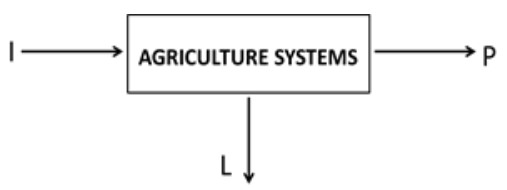

Figure 1 . The simple model $(\mathrm{I}=$ input, $\mathrm{P}=$ product, $\mathrm{L}=$ loss). Therefore, $\mathrm{I}=\mathrm{P}+\mathrm{L}$; and Efficiency $(\mathrm{E})=\mathrm{P} / \mathrm{I}$

Nitrogen content of the products or outputs of agriculture (plant and animal) was calculated based on the production data obtained from BPS (2010). Total Nitrogen in product $(\mathrm{P})$ was calculated by dividing protein content and the correction factor of 6.25 (Lee 1975): Total nitrogen $=$ Protein content $(\%) / 6.25$.

For the simple model, the output consists of plants and animals refer to the main crops (rice, cassava, sweet potatoes, peanuts, soybeans, and maize) and animals (cattle, buffalo, horse, goat, sheep, pig, chicken, duck, egg, dairy, and fish). Table 1 describes the calculation of the nitrogen balance in the simple model.

\subsection{The Complex Model}

The complex model was developed from the simple model to describe a more real situation of the agriculture system in Indonesia. This model consists of four compartments, namely:

a. Plant includes crops produced or part of plants that can be consumed by animals and fish.

b. Animals act as consumers and produce nutrients stored in the animals.

c. Fish act as consumers and produce nutrients stored in the fish.

d. Soil consists of organic nutrient exchange and mineral components of soil.

Table 1. Nitrogen balance of the simple model for Indonesian

\begin{tabular}{lcc}
\multicolumn{4}{c}{ agriculture around 1968 and 2008} \\
\hline & $\begin{array}{c}1968 \\
(\mathrm{Kg} \mathrm{N} / \mathrm{ha})\end{array}$ & $\begin{array}{c}2008 \\
(\mathrm{Kg} \mathrm{N} / \mathrm{ha})\end{array}$ \\
\hline $\begin{array}{l}\text { Input } \\
\text { Fertilizer }\end{array}$ & 10 & 160
\end{tabular}


Nitrogen fixation

Atmospheric deposition

Soil bacterial fixation

Total

Output

Plant

Animal

Total

Lost to environment

Efficiency (\%)

Notes: Effective arable land were about 9,000,000 ha (1968) and $18,000,000$ ha (2008)

Inputs will go into each compartment through the internal flows of nitrogen that connect between compartments. Nitrogen inputs were used to identify the system, including: fertiliser, plant $\mathrm{N}_{2}$ fixation, soil bacteria fixation, and atmospheric deposition. The output consists of products produced from crops, livestock, and fish. Nitrogen loss through volatilisation of $\mathrm{NH}_{3}$, evaporation of $\mathrm{N}_{2} \mathrm{O}$ and $\mathrm{N}_{2}$ from (denitrification), and leaching of nitrate (nitrification) (Figure 2 and description of the symbols used are in Table 2). Ribaudo et al. (2011) describe the balance and efficiency of nitrogen use into input (fertiliser, manure and miscellaneous atmospheric deposition), output ( $\mathrm{N}$ in harvested crops), $\mathrm{N}$ leaching, $\mathrm{N}$ erosion and gaseous $\mathrm{N}$ losses and internal $\mathrm{N}$ pools of crop residue $\mathrm{N}$, soil organic $\mathrm{N}$, soil inorganic $\mathrm{N}$, and net $\mathrm{N}$ mineralisation.

The compartment was detailed further to reduce its drawbacks by showing specifically the internal flows and loss of nitrogen. Therefore, the internal flow of nitrogen is more complex and specific in accordance with the real situation of Indonesian agroecosystems. This model divides the compartment into 10 sub-compartments that are needed to build a more comprehensive and representative model. At the complex farming systems model, 30 variables exist that consist of 4 independent variables $\left(\mathrm{I}_{1}, \mathrm{I}_{4}, \mathrm{~J}_{4}\right.$, and $\mathrm{K}_{4}$, ) as input and 26 dependent variables. From the dependent variables then obtained 26 equations that can be classified into 10 equations of mass balance and 16 efficiency equations. The following are mathematical equations and explanation of 30 variables used in the model.

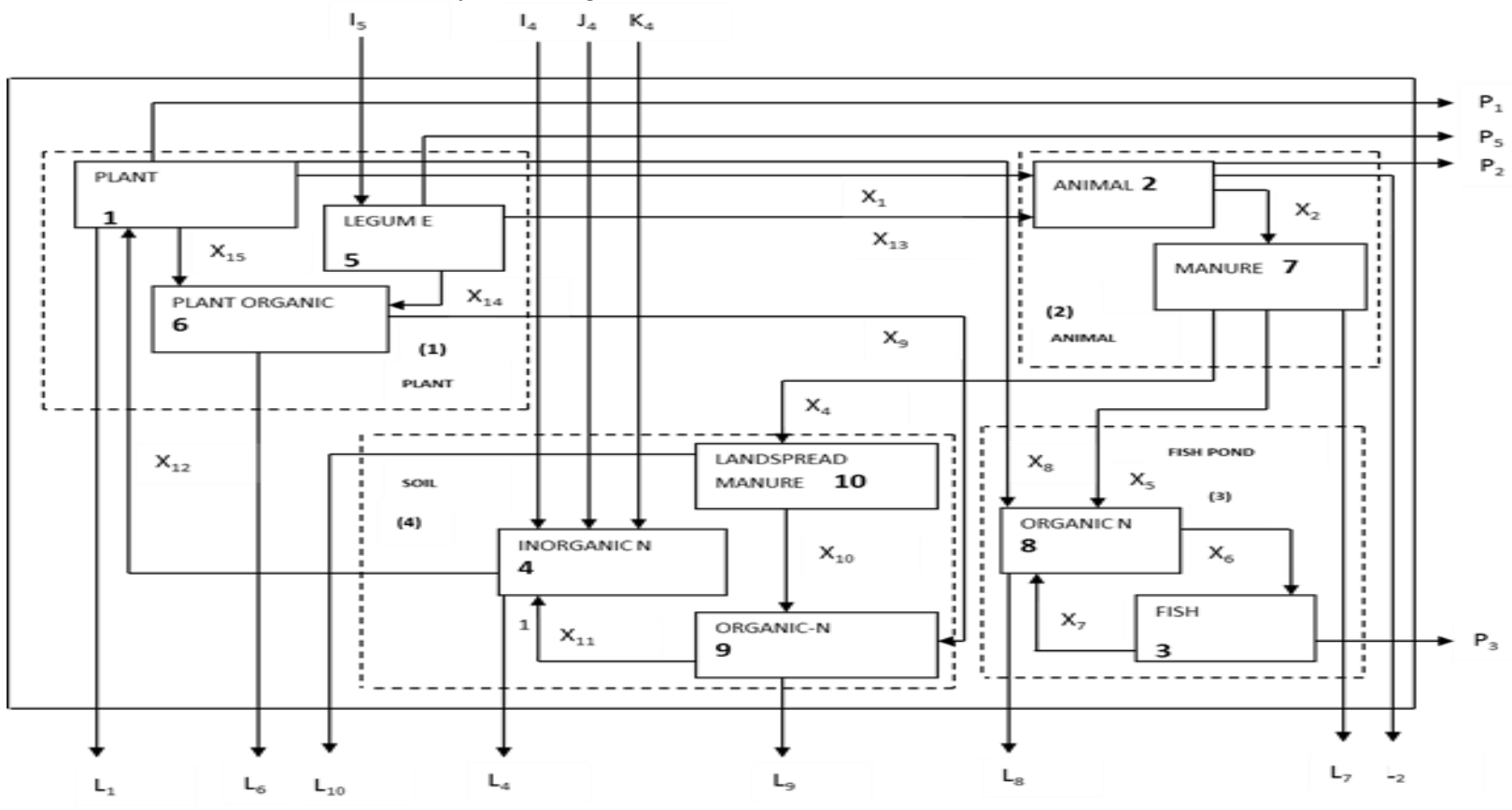

Figure 2. The complex model

\section{Mass Balance Equations}

Compartment $1: \mathrm{X}_{12}-\mathrm{X}_{1}-\mathrm{X}_{8}-\mathrm{X}_{15}-\mathrm{P}_{1}-\mathrm{L}_{1}=0$

Compartment 2: $\mathrm{X}_{1}+\mathrm{X}_{13}-\mathrm{X}_{2}-\mathrm{P}_{2}-\mathrm{L}_{2}=0$

Compartment $3: \mathrm{X}_{6}-\mathrm{X}_{7}-\mathrm{P}_{3}=0$

Compartment $4: \mathrm{I}_{4}+\mathrm{J}_{4}+\mathrm{K}_{4}+\mathrm{X}_{11}-\mathrm{X}_{12}-\mathrm{L}_{4}=0$

Compartment $5: \mathrm{I}_{5}-\mathrm{X}_{14}-\mathrm{X}_{13}-\mathrm{P}_{5}=0$

Compartment $6: \mathrm{X}_{14}+\mathrm{X}_{15}-\mathrm{X}_{9}-\mathrm{L}_{6}=0$.

Compartment $7: \mathrm{X}_{2}-\mathrm{X}_{4}-\mathrm{X}_{5}-\mathrm{L}_{7}=0$

Compartment $8: \mathrm{X}_{5}+\mathrm{X}_{7}+\mathrm{X}_{8}-\mathrm{X}_{6}-\mathrm{L}_{8}=0$

Compartment $9: \mathrm{X}_{9}+\mathrm{X}_{10}-\mathrm{X}_{11}-\mathrm{L}_{9}=0$

Compartment $10: \mathrm{X}_{4}-\mathrm{X}_{10}-\mathrm{L}_{10}=0$

\section{Efficiency Equations}

Compartment 1

Efficiency in plant production $\left(\mathrm{a}_{1}\right)$

$\mathrm{a}_{1}=\frac{X 1+X 8+X 15+P 1}{X 12}=\frac{N \text { produced by plant }}{N \text { uptaken by plant }}$

$\mathrm{N}$ in edible part of plant $\left(\mathrm{a}_{2}\right)$

$\mathrm{a}_{2}=\frac{P 1+X 1+X 8}{X 12}=\frac{\text { Edible } \text { part of plant }}{N \text { uptaken by plant }}$ 
ISSN 2086-4639 | e-ISSN 2460-5824 JPSL Vol. 8 (3): 308-318

Plant waste utilisation ( $\mathrm{a}_{3}$ and $\left.\mathrm{a}_{4}\right)$

$\mathrm{a}_{3}=\frac{X 1}{X 1+X 8+P 1}=\frac{\text { Part of plant consumed by animal }}{\text { Edible part of plant }}$

$\mathrm{a}_{4}=\frac{X 8}{X 1+X 8+P 1}=\frac{P \text { ert of plant consumed by fish }}{\text { Edible part of plant }}$

\section{Compartment 2}

Efficiency in animal production (a5)

$\mathrm{a}_{5}=\frac{P 2}{X 1+X 13}=\frac{\text { Edible part of animal }}{\text { Part of plant consumed by animal }}$

Manure loss fraction (a6)

$\mathrm{a}_{6}=\frac{L 2}{X 2+L 2}=\frac{\text { Manure lost }}{\text { Total produced manure }}$

\section{Compartment 3}

Fish product utilisation (a)

$\mathrm{a}_{7}=\frac{P 3}{X 6}=\frac{\text { Edible part of } \mathrm{fish}}{N \text { consumed } \text { by } \text { fish }}$

\section{Compartment 4}

Nitrogen denitrification $\left(\mathrm{a}_{8}\right)$

$\mathrm{a}_{8}=\frac{L 4}{I 4+K 4+X 11+J 4}=\frac{N \text { lost from soil }}{N \text { totalsupplied to soil }}$

\section{Compartment 5}

Legume utilisation (a9)

$\mathrm{a}_{9}=\frac{X 13}{X 13+P 5}=\frac{\text { Part of legume consumed } \text { by animal }}{\text { Edible part of plant }}$

$\mathrm{a}_{10}=\frac{X 13+P 5}{I 5}=\frac{\text { Edible part of legume }}{\text { N uptaken by legume }}$

\section{Compartment 6}

Utilisation of plant wastes $\left(\mathrm{a}_{11}\right)$

$\mathrm{a}_{11}=\frac{X 9}{X 14}=\frac{\text { Organic } N \text { in soil }}{N \text { in legume } \text { wastes }}$

\section{Compartment 7}

Manure utilisation ( $\mathrm{a}_{12}$ and $\mathrm{a}_{13}$ )

$\mathrm{a}_{12}=\frac{X 4}{X 4+X 5+L 7}=\frac{\text { Manure spread in soil }}{\text { Total produced manure }}$

$\mathrm{a}_{13}=\frac{X 5}{X 4+X 5+L 7}=\frac{\text { Manure used in pond }}{\text { Total produced manure }}$

Compartment 8

$\mathrm{N}$ utilisation in fishpond $\left(\mathrm{a}_{14}\right)$

$\mathrm{a}_{14}=\frac{X 6}{X 8}=\frac{N \text { consumed } \text { by } \text { fish }}{\text { Total manure to } \text { fishpond }}$

\section{Compartment 9}

Organic N mineralisation ( $\left.\mathrm{a}_{15}\right)$

$\mathrm{a}_{15}=\frac{X 11}{X 9}=\frac{\text { Miniralised organic } N}{\text { Total } N \text { organic into soil }}$

\section{Compartment 10}

Efficiency of $\mathrm{N}$ manure in soil organic (a16)

$\mathrm{a}_{16}=\frac{X 10}{X 4}=\frac{\text { Manure in the soil }}{\text { Manure spread to soil }}$

$\mathrm{N}$ distribution in legume $\left(\mathrm{a}_{10}\right)$

Table 2. Symbols used in the complex model

\begin{tabular}{ll}
\hline Input & Output \\
\hline $\mathrm{I}_{5}=$ Plant nitrogen fixation & $\mathrm{P}_{1}=$ Edible part of the plant \\
$\mathrm{I}_{4}=$ Fertilizer nitrogen & $\mathrm{P}_{2}=$ Edible part of the animal \\
$\mathrm{J}_{4}=$ Soil bacterial fixation & $\mathrm{P}_{3}=$ Edible part of the fish \\
$\mathrm{K}_{4}=$ Atmospheric deposition & $\mathrm{P}_{4}=$ Edible part of legume \\
Looses & Internal Flows \\
$\mathrm{L}_{1}=$ Ammonia volatilization from the plant & $\mathrm{X}_{1}=$ Part of plant nitrogen as animal \\
$\mathrm{L}_{2}=$ Animal nitrogen loss to the environment & $\mathrm{X}_{2}=$ Nitrogen manure \\
$\mathrm{L}_{4}=$ Nitrogen loss through denitrification & $\mathrm{X}_{4}=$ Nitrogen manure enter the soil \\
$\mathrm{L}_{6}=$ Nitrate leaching & $\mathrm{X}_{5}=$ Nitrogen manure to fish pond \\
$\mathrm{L}_{7}=$ Nitrogen manure lost & $\mathrm{X}_{6}=$ Nitrogen consumed by fish \\
$\mathrm{L}_{8}=$ Fish feed lost to the environment & $\mathrm{X}_{7}=$ Nitrogen in fish pond mud \\
$\mathrm{L}_{9}=$ Nitrogen lost from ammonification & $\mathrm{X}_{8}=$ Plant nitrogen as fish feed \\
$\mathrm{L}_{10}=$ Nitrogen manure lost from the soil surface & $\mathrm{X}_{9}=$ Plant nitrogen left in the soil organic \\
& $\mathrm{X}_{10}=$ Nitrogen manure enter the soil \\
& $\mathrm{X}_{11}=$ organic nitrogen converted to inorganic nitrogen in the soil \\
& $\mathrm{X}_{12}=$ Nitrogen inorganic up taken by plant \\
& $\mathrm{X}_{13}=$ Legume nitrogen as animal feed \\
& $\mathrm{X}_{14}=$ Nitrogen in plant residue \\
& $\mathrm{X}_{15}=$ Nitrogen from plant residue \\
\hline
\end{tabular}

Table 3 summarised the value of efficiency factors collected, reviewed or calculated from relevant literatures. These values were used in the calculation of respective variables using Microsoft Excell.

The complex model outputs are shown in Figure 3 (1968) and Figure 4 (2008). These figures show internal and external flows (as cycle). Based on these cycles, the changes in the total efficiency of agricultural systems can be calculated (Table 4). The results of both models show a similar trend of decreased efficiency within 40 years of nitrogen application. The changes are decreasing in biological nitrogen fixation and increasing of losses 
caused by increased in nitrogen fertiliser application.

Comparing input to increased output revealed that the output improvement by 2 - folds need addition of input by 3 -folds, and follow by increasing loss by 3.5 -fold. Increased input mainly associated with mineral fertiliser, especially nitrogen by 16 -folds. Concerning the fertiliser alone, this addition leads to a decrease of legumes nitrogen fixation from the air and reduce the efficiency of absorption (Graham and Vance, 2003). Similarly, the soil bacteria capability to fix nitrogen decreased significantly by increased of mineral nitrogen application (Peoples $e t$ al. 1995; Galloway et al. 2004; Berthrong et al., 2014). Therefore, intensive agricultural systems actually losing nitrogen by boosting the production through addition of mineral fertiliser. Globally, as mentioned by Tilman (1999), the doubling of agricultural food production was associated with a 6.87-fold increase in nitrogen fertilisation and a 3.48-fold increase in phosphorus fertilisation. A more serious problem (Lin et al. 2008) would happen from synergism of climate change and intensification that cause vulnerability for crops.

Table 3. Efficiency factors in the complex model

\begin{tabular}{ccl}
\hline Symbol & Value & References \\
\hline $\mathrm{a}_{1}$ & 0.87 & $\begin{array}{l}\text { Achmadi (2010); BPS (2010); } \\
\text { Simanungkalit } \text { et al. (2006); Soemarsono } \\
\end{array}$ \\
$\mathrm{a}_{2}$ & 0.66 & Sugiyanta (2007) \\
$\mathrm{a}_{3}$ & 0.10 & Bantacut (1992) \\
$\mathrm{a}_{4}$ & 0.05 & Bantacut (1992) \\
$\mathrm{a}_{5}$ & 0.25 & Achmadi (2010) \\
$\mathrm{a}_{6}$ & 0.85 & Sutanto (2002) \\
$\mathrm{a}_{7}$ & 0.65 & Wiramiharja et al. (2005) \\
$\mathrm{a}_{8}$ & 0.50 & Suganda and Kurnia (2005) \\
$\mathrm{a}_{9}$ & 0.10 & Sukria and Rantan (2009) \\
$\mathrm{a}_{10}$ & 0.50 & Sutanto (2002) \\
$\mathrm{a}_{11}$ & 0.80 & Sutanto (2002) \\
$\mathrm{a}_{12}$ & 0.73 & Atmojo (2003) \\
$\mathrm{a}_{13}$ & 0.03 & Sutanto (2002) \\
$\mathrm{a}_{14}$ & 0.38 & Wiramiharja et al. (2005) \\
$\mathrm{a}_{15}$ & 0.40 & Hanafiah (2007) \\
$\mathrm{a}_{16}$ & 0.60 & Hanafiah (2007) \\
\hline
\end{tabular}

Table 4. The complex model nitrogen balance ( $\mathrm{kg} \mathrm{N} / \mathrm{ha}$.year)

\begin{tabular}{lcc}
\hline Component & 1968 & 2008 \\
\hline Input & 74 & 203 \\
Output & 30 & 65 \\
Loss & 40 & 141 \\
Effisiency (\%) & 41 & 32 \\
\hline
\end{tabular}

\section{Nitrogen Lost to the Environment and Its Impact}

Loss of $\mathrm{N}$-fertiliser results from gaseous plant emission, soil denitrification, surface runoff, volatilisation, and leaching (Raun and Johnson, 1999) and plant canopy (Fageria and Baligar, 2005). The model calculations show nitrogen losses to the surrounding environment $40 \mathrm{~kg} \mathrm{~N} / \mathrm{ha}$ in 1968 increased to $141 \mathrm{~kg} \mathrm{~N} / \mathrm{ha}$ in 2008. This increase was mainly caused by the addition in fertiliser application from $10 \mathrm{~kg} \mathrm{~N} / \mathrm{ha}$ in 1968 to 160 $\mathrm{kg} \mathrm{N} / \mathrm{ha}$ in 2008 (Table 5).

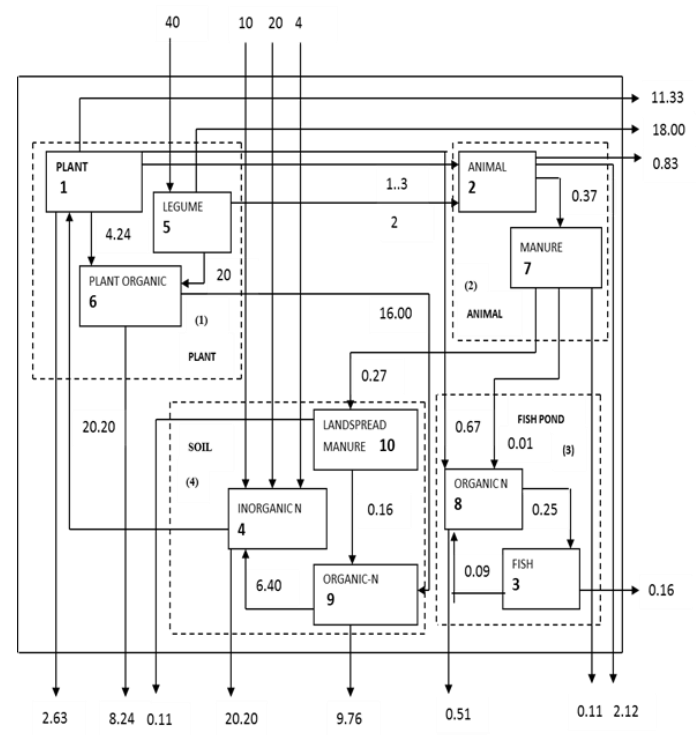

Figure 3. Nitrogen cycle in Indonesia agriculture 1968 ( $\mathrm{kg}-\mathrm{N} / \mathrm{ha})$

The model outputs show that there is a positive correlation between the amount of $\mathrm{N}$-fertiliser application and $\mathrm{N}$ losses to the environment. The amount of $\mathrm{N}$ lost to the environment mainly occurs through denitrification, nitrate leaching, and ammonia volatilisation. Fertiliser applications is constantly increasing every year that cause significant increase of $\mathrm{N}$ lost to the environment. For example, the average application of fertiliser on food crops in 2008 about $160 \mathrm{~kg} \mathrm{~N} / \mathrm{ha}$ caused nitrogen lost to the surrounding environment about $141 \mathrm{~kg} \mathrm{~N} / \mathrm{ha}$. This means that most of nitrogen inputting to agricultural systems will finally loss to the environment.

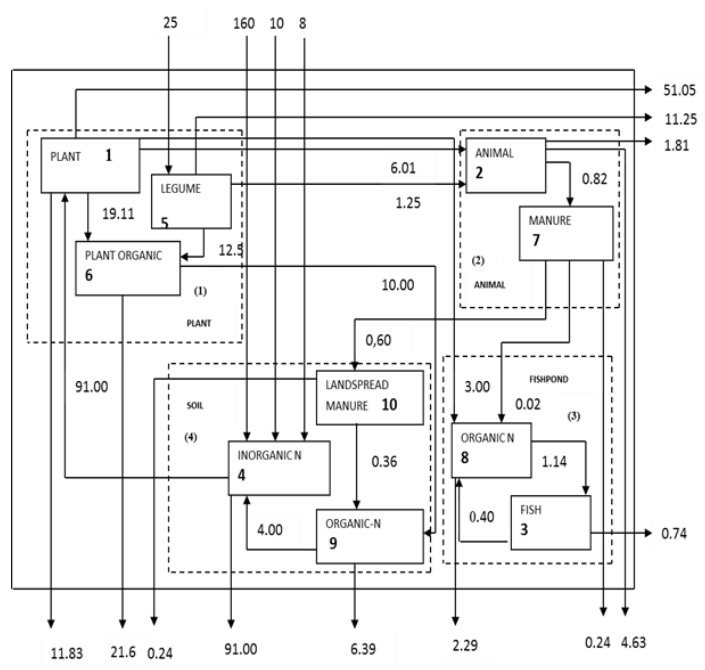


Figure 4. Nitrogen cycle in Indonesian agriculture 2008 (kg$\mathrm{N} / \mathrm{ha}$ )

Table 5. Nitrogen lost from Indonesia agroecosystems 1968 and 2008

\begin{tabular}{lccr}
\hline \multirow{2}{*}{ Type of losses } & \multirow{2}{*}{ Symbol } & \multicolumn{2}{c}{ Amount (kg } \\
\cline { 3 - 4 } & & 1968 & 2008 \\
\hline $\begin{array}{l}\text { Ammonia volatilization from the } \\
\text { plant }\end{array}$ & $\mathrm{L}_{1}$ & 2.63 & 11.8 \\
$\begin{array}{l}\text { Animal nitrogen loss to the } \\
\text { environment }\end{array}$ & $\mathrm{L}_{2}$ & 2.12 & 4.63 \\
$\begin{array}{l}\text { Nitrogen loss through } \\
\text { denitrification }\end{array}$ & $\mathrm{L}_{4}$ & 20.2 & 91.0 \\
$\begin{array}{l}\text { Nitrate leaching } \\
\text { Nitrogen manure lost }\end{array}$ & $\mathrm{L}_{6}$ & 8.24 & 21.6 \\
$\begin{array}{l}\text { Fish feed lost to the environment } \\
\text { Nitrogen lost from }\end{array}$ & $\mathrm{L}_{7}$ & 0.1 & 0.2 \\
ammonification & $\mathrm{L}_{8}$ & 0.51 & 2.29 \\
$\begin{array}{l}\text { Nitrogen manure lost from the } \\
\text { soil surface }\end{array}$ & $\mathrm{L}_{9}$ & 6.39 & 9.76 \\
Total Nitroegen lost & $\mathrm{L}_{10}$ & 0.11 & 0.24 \\
\hline
\end{tabular}

Laboratory scale research revealed that fertiliser much correlated with $\mathrm{N}_{2}$ and $\mathrm{N}_{2} \mathrm{O}$ emissions (Mulvaney et al., 1997). Fertiliser addition affects both the activity and the composition of denitrifying communities in arable soil on a long-term basis (Enwall et al., 2005). The more fertiliser use, the denitrification process releasing nitrogen is higher. In the tropical zone, where sun radiation is longer, denitrification process is at higher rate and caused higher emission rate (Sehy et al., 2003). Then, denitrification process releasing $\mathrm{N}$ to the environment is a common phenomenon of the nitrogen cycle which rate accelerated by mineral $\mathrm{N}$ fertiliser application.

Nitrate leaching reaches the depth of soil then converted to nitrate through nitrification by microorganisms. Due to negatively charge of nitrate can reach ground water as much as $2-10 \%$ of nitrogen fertiliser applied (Savci, 2012). The ground water nitrate concentration varies according to type of plant and planting pattern. For example in the Philippine, in irrigated double rice cropping areas, seasonal-mean nitrate concentrations were $0-2 \mathrm{mg} / \mathrm{l}$ in wet season rainfed rice and dry season irrigated sweet pepper double cropping areas, monthly mean nitrate concentrations were $5-12 \mathrm{mg} / 1$ (Bouman et al., 2002). The similar research is not yet available in Indonesia, but comparing to the nitrogen fertiliser rate was $115 \mathrm{~kg} / \mathrm{ha}$ arable land (2008) in the Philippines is smaller than Indonesia, then it is acceptable to mention that the ground water nitrate concentration is also higher (http://www.indexmundi.com/facts/philippines/fertiliserconsumption).

$\mathrm{N}$-fertiliser and manure cause harmful environmental effects including leaching of nitrate into ground water, nitrogen run-off, and eutrophication of aquatic ecosystems (Adesemoye and Kloepper, 2009). Nitrate leaching occurs when $\mathrm{NO}^{-}$accumulate in the soil profile that coincides with or is followed by a long period of high drainage. Excessive nitrogen fertiliser application followed with long period of submerged condition (as in the wet rice field) can all potentially lead to high nitrate leaching losses. Therefore, nitrate leaching from agricultural production systems is blamed for the rising concentrations of $\mathrm{NO}^{-}$in ground-water and surfacewaters around the world (Di and Cameron 2002). The amount of nitrate leached increased linearly proportional to increased $\mathrm{N}$-fertiliser applied at planting (Errebhi et al., 1998).

Certain processes and mechanisms involved in the production and transfer of ammonia $\left(\mathrm{NH}_{3}\right)$ to the atmosphere from agricultural sources. Animal production systems are recognized as the major source of $\mathrm{NH}_{3}$. These releases have environmental and agricultural implications. Larger proportions of the $\mathrm{N}$ ingested by animals especially under intensive management regimes. These losses are: (i) proportional to $\mathrm{N}$ input (whether from fertiliser or through $\mathrm{N}_{2}$ fixation); (ii) highly variable over both the short and the longer-term; and (iii) influenced by particular management methods and animal species. Losses of $\mathrm{NH}_{3}$ resulting directly from housed animals, from stored farm wastes and during or after land manure spreading, give the major proportion of the $\mathrm{NH}_{3}$ losses from animal production (Jarvis and Pain, 1990). In rice field, ammonia volatilisation is a response to urea application. Total $\mathrm{N}$ losses through ammonia volatilisation generally increased with the $\mathrm{N}$ application rate. Total loss by ammonia volatilisation during the entire rice growth stage ranged from $9.0 \%$ to $16.7 \%$ of the applied $\mathrm{N}$ (Lin et al., 2007). Ammonia volatilisation is affected by the soil, plant and micro-climate (Harper $e t$ al., 1983).

At global scale, the increase of reactive nitrogen emissions to the environment may contribute to harmful changes to ecosystems (Ribaudo et al., 2011): (i) ozoneinduced injury to crop, forest, and natural ecosystems, (ii) acidification and eutrophication (nutrient enrichment) effects on forests, (iii) soils, and freshwater aquatic ecosystems, (iv) eutrophication and hypoxia (oxygen depletion) in coastal and lake ecosystems, (v) harmful algae blooms, (vi) biodiversity losses in terrestrial and aquatic ecosystems, (vii) regional haze, (viii) depletion of stratospheric ozone, (ix) global climate change, and (x) nitrate contamination of drinking water aquifers.

In Indonesia, many research found that nitrogen lost to the environment have an impact on the pollution of rivers and lakes. For examples are cases on the river in West Java. Up to 2007 water quality in the river showed poor condition. Results of a study of seven major rivers namely Cimanuk, Citarum, Cisadane, Bekasi, Ciliwung, Citanduy and Cilamaya, all of which indicate the status of the quality of very poor condition (KNLH, 2010). Results of monitoring conducted in 2008 by 30 BAPEDAL (Environmetal Impact Control Agency) for 35 rivers province in Indonesia showed that the status of water quality in general is heavily polluted (BPS, 2010). Sutami reservoir in East Java is at a critical condition 
caused major agricultural pollutants mainly detected in the reservoir were organic $\mathrm{N}(1,044$ ton/year $)$ and $\mathrm{NO}_{3}$ (3,298 ton/year), respectively. Fertiliser use at the normal rate can cause an increase of nutrient load (organic N, organic $\mathrm{P}, \mathrm{NO}_{2}$, and $\mathrm{NO}_{3}$ ) at the reservoir of $21 \%$ to $50 \%$ (Othman and Sholichin, 2008).

Fertiliser pollution has caused the significant increase in local radioactivity (Udiyani and Setiawan 2003). After 30-40 years of intensive use of fertiliser in lowland areas of West Java, the concentration in the soil of heavy metals such as lead and cadmium has reached a measurable level although remains below toxic levels (Setyorini et al., 2005). Gaseous nitrogen will form the ambient air composition together with natural and other emission sources which finally may be deposited in the agriculture area. This is a miscellaneous input to agriculture from the atmosphere which amount increase after the air pollution level. This source is the only one that increase relatively linear to the amount of fertiliser application.

\section{Nutrient Management Implication}

The main goal of intensification is to increase production by adding necessary inputs and applying technology. However, production improvement is always coupled with environmental pollution that caused by chemicals release, one of them is fertiliser lost, to the environment. The future task is how to increase or at least keep up the production while protecting the environment through fertiliser (nitrogen) use efficiency improvement, reducing excessive input of fertilisers, and maintaining an acceptable yield (Hirel et al., 2007). From the model, it can be calculated that the same output of 2008 at 1968 efficiency may be met with total input only $160 \mathrm{~kg}$ $\mathrm{N} /$ ha.year or fertiliser $\mathrm{N}$ of $117 \mathrm{~kg} / \mathrm{ha}$.year, cut the fertiliser use by $27 \%$. Similarly, the same efficiency at current fertiliser rate would produce about $83 \mathrm{~kg}$ $\mathrm{N} /$ ha.year. This efficiency improvement will cut the Nlost to the environment by $33 \%$ and $15 \%$ respectively. These alternatives of efficiency improvement show that reducing the input and improvement of efficiency will be a major challenge for crops researchers and farmers. It is also a better way of meeting food demand while maintaining environmental quality.

Technically, many ways are available to improve Nfertiliser efficiency. Datta (1986) proposed: (i) improved timing and application methods, and particularly through better incorporation of basal $\mathrm{N}$-fertiliser without standing water, (ii) use of $\mathrm{N}$-efficient plant (rice) varieties, (iii) deep placement of fertiliser (urea) supergranules, and (iv) use of slow release N-fertilisers. Chien et al. (2009) detailed some $\mathrm{N}$ nutrient efficiency improvements include (i) controlled-release coated urea products, (ii) slow-release urea-aldehyde polymer products, (iii) urea supergranules for deep placement, (iv) nitrification inhibitors to cut nitrate leaching and denitrification, (v) urease inhibitors to reduce ammonia volatilisation from urea, and (vi) ammonium sulphate to enhance $\mathrm{N}$ efficiency of urea. These efforts may result in an increased relative economic benefit for saving fertiliser cost, enhancing nutrient efficiency, or increasing crop yield. In a management sense, Fageria and Baligar (2005) argue that $\mathrm{N}$ efficiency improvement must consider these technical issues along with soil and crop management practices. For example, livestock production with cropping offers one of the best opportunities, and synchrony of $\mathrm{N}$ supply with crop demand is essential to ensure adequate quantity of uptake, utilisation and optimum yield.

Snyder et al. (2009) mention some available nitrogen management measures include: (i) right $\mathrm{N}$-fertiliser use (ii) best management practices (iii) tillage practice, and (iv) differences among $\mathrm{N}$-fertiliser sources. These and many other measures can give some benefits such as (i) helps increase biomass production necessary to help restore and keep up soil organic carbon (SOC) levels, (ii) minimise residual soil nitrate, which helps lower the risk of increased nitrous oxide $\left(\mathrm{N}_{2} \mathrm{O}\right)$ emissions, (iii) reduce soil disturbance and maintain crop residue on the soil surface to increase SOC levels, and Ventere, et al. (2005) concern with cutting nitrogen oxide and methane emission.

Grinsven et al. (2012) state and evaluate the implementation of the Nitrates Directive (NiD) policy in the northwest of the European Union (Ireland, United Kingdom, Denmark, the Netherlands, Belgium, Northern France and Germany). This policy restricts the use of fertiliser and manure application has contributed to the decrease of the nitrogen soil $\mathrm{N}$ balance and by that of the gross $\mathrm{N}$ load to the aquatic environment. Therefore, such a policy might be applicable for the Indonesian agriculture practice to control the environmental pollution caused by the excessive use of mineral fertiliser.

The main concern of fertiliser application research in Indonesia has been on optimal and balanced fertiliser to improve yield (Wahid, 2003). The fertiliser related pollutions existence warn that the future agriculture is no longer to maximise production, rather it is to optimise the production and minimising pollution. Ignoring environmental pollution for long time will be a catastrophe of crops production. Therefore, more research and practical efforts (applied research) is required to find best farming practices with better fertiliser use efficiency and lower fertiliser wasting to the environment. Increase the obtaining $\mathrm{N}$ from legumes is potentially more sustainable than from industrial sources (Crews and Peoples, 2004). Indonesia is a country which has the capacity to greatly reduce or eliminate dependence on synthetic $\mathrm{N}$ through application of organic fertiliser, nitrogen fixing plant, and even changing the staple food (Bantacut, 2014). Integrated nutrient management systems are needed to maintain agricultural productivity and protect the environment. Microbial 
inoculants are promising components of such management systems (Adesemoye and Kloepper 2009).

\section{Conclusion}

The balance models show that the efficiency of nitrogen uptake has been decreasing from 1968 to 2008 . This 40 years of fertiliser application history convinced that nitrogen loss to the environment is increasing following the level of its application. Maintaining productivity will need more fertiliser application then nitrogen losses is expected to increase and worsen the environmental pollution. N-loss can occur through ammonia volatilisation, leaching of nitrate (nitrification), and evaporation from the soil $\mathrm{N}_{2} \mathrm{O}$ and $\mathrm{N}_{2}$ (denitrification).

Agricultural production in Indonesia is increasing every year. Dominant factors to increase production are increased fertiliser application, improved crop varieties, better land preparation, expanding agricultural land, irrigation development, and the increased application of pesticides. On the other hand, an increase in agricultural production brings the adverse effects on the environment such as river and groundwater pollution are already exits. Therefore, it is necessary to manage environmental pollution by controlling and reducing the use of fertilisers and chemicals through the efficiency improvement. Alternatively, the use of organic fertilisers and leguminous plants should be improved. An increase of plant variety and minimise nitrogen loss to the environment should also be done. Reducing and controlling the use of chemicals in farming and solving the environmental problems should in line with maintaining the quality and quantity of agricultural production.

\section{References}

[1] Abraham, B., H. Araya, T. Berhe, S. Edwards, B. Gujja, R.B. Khadka, Y.S. Koma, D. Sen, A. Sharif, E. Styger, N. Uphoff, A. Verma, 2014. The system of crop intensification: reports from the field on improving agricultural production, food security, and resilience to climate change for multiple crops. Agriculture \& Food Security 3(4), pp. 1-12. doi:10.1186/2048-7010-3-4.

[2] Achmadi, J., 2010. Pengembangan pakan ternak ruminansia: menggagas lumbung pakan berbasis hasil samping tanaman pangan (Development of ruminant feed: initiating byproduct crop based feed barn). http://eprints.undip.ac.id/25147/1/JAC_pengempak.pdf. $\quad[29$ November 2011].

[3] Adesemoye, A.O., J.W. Kloepper, 2009. Plant-microbes interactions in enhanced fertiliser-use efficiency. Applied Microbiology and Biotechnology, Vol. 85(1), pp. 1-12.

[4] Adi., 2010. Intensifikasi pertanian lahan kering. http://authpass.wordpress.com/2010/11/10/intensifikasipertanian-lahan-kering/. [8 Februari 2011].

[5] Atmojo, S.W., 2003. Peranan bahan organik terhadap kesuburan tanah dan upaya pengelolaannya. http://suntoro.staff.uns.ac.id/files/2009/04/pengukuhan-profsuntoro.pdf [18 November 2011].
[6] Baligar, V.C., O.L. Bennett, 1986. NPK-fertilizer efficiency - a situation analysis for the tropics. Fertilizer Research 10(2), pp.147-164.

[7] Baligar, V.C., N.K. Fageria, Z.L. Hea, 2001. Nutrient Use Efficiency in Plants. Communications in Soil Science and Plant Analysis 32(7-8), pp. 921-950.

[8] Bantacut, T., 1992. Environment Impacts of Agricultural Intensification in Indonesia. Unpublished Master Thesis, Asian Institute of Technology, Bangkok, Thailand.

[9] Bantacut, T., 2014. Indonesian Staple Food Adaptations for Sustainability in Continuously Changing Climates. Journal of Environment and Earth Science 4(21), pp.202-215.

[10] Berthrong, S.T., C.M. Yeager, L. Gallegos-Graves, B. Steven, S.A. Eichorst, R.B. Jackson, C.R. Kuske, 2014. Nitrogen fertilization has a stronger effect on soil nitrogen-fixing bacterial communities than elevated atmospheric $\mathrm{CO}_{2}$. Applied Environmental Microbiology 80(10), pp. 3103-12.

[11] Bouman, B.A.M., A.R. Castañeda, S.I. Bhuiyan, 2002. Nitrate and pesticide contamination of groundwater under rice-based cropping systems: past and current evidence from the Philippines. Agriculture, Ecosystems \& Environment. 92(2-3), pp.185-199.

[12] Burney, J.A., S.J. Davis, D.B. Lobella, 2010. Greenhouse gas mitigation by agricultural intensification. Proceedings of the National Academy of Sciences of the United States of America 107(26), pp.12052-12057.

[13] [BPS] Biro Pusat Statistik., 1991. Indicator of Agriculture. Pusat Biro Statistik. Jakarta

[14] [BPS] Biro Pusat Statistik, 2010. Statistical Year Book of Indonesia. Pusat Biro Statistik. Jakarta.

[15] Chien, S.H., L.I. Prochnow, H. Cantarella, 2009. Recent Developments of Fertilizer Production and Use to Improve Nutrient Efficiency and MinimiseEnvironmental Impacts. Advances in Agronomy 102, pp.267-322.

[16] Crews, T.E., M.B. Peoples, 2004. Legume versus fertilizer sources of nitrogen: ecological tradeoffs and human needs. Agriculture, Ecosystems \& Environment 102(3), pp.279-297.

[17] S.K. De Datta, 1986. Improving nitrogen fertilizer efficiency in lowland rice in tropical Asia. Fertilizer Research 9(1-2), pp.171186.

[18] Daubresse, C.M., F.D. Vedele, J. Dechorgnat, F. Chardon, L. Gaufichon, A. Suzuki, 2010. Nitrogen uptake, assimilation and remobilization in plants: challenges for sustainable and productive agriculture. Annals of Botany 105, pp.1141-1157.

[19] Di, H.J., K.C. Cameron, 2002. Nitrate leaching in temperate agroecosystems: sources, factors and mitigating strategies. Nutrient Cycling in Agroecosystems 64(3), pp.237-256.

[20] Edgerton, M.D., 2009. Increasing Crop Productivity to Meet Global Needs for Feed, Food, and Fuel. Plant Physiology 149(1), pp.7-13.

[21] Enwall, K., L. Philippot, S. Hallin, 2005. Activity and Composition of the Denitrifying Bacterial Community Respond Differently to Long-Term Fertilization. Applied Environmental Microbiology 71(12), pp.8335-8343. doi: 10.1128/AEM.71.12.8335-8343.2005.

[22] Errebhi, M., C.J. Rosen, S.C. Gupta, D.E. Birong, 1998. 'Potato Yield Response and Nitrate Leaching as Influenced by Nitrogen Management. Agronomy Journal 90, pp.10-15. doi:10.2134/agronj1998.00021962009000010003x.

[23] Fageria, N.K. V.C. Baligar, 2005. Enhancing Nitrogen Use Efficiency in Crop Plants. Advances in Agronomy 88, pp.97185.

[24] Galloway, J.N., F.J. Dentener, D.G. Capone, E.W. Boyer, R.W. Howarth, S.P Seitzinger, G.P. Asner, C.C. Cleveland, P.A. Green, E.A. Holland, 2004. Nitrogen Cycles: Past, Present, and Future. Biogeochemistry 70(2), pp.153-226.

[25] Giller, K.E., M.H. Beare, P. Lavelle, A-M.N. Izac, M.J. Swift, 1997. Agricultural intensification, soil biodiversity and agroecosystem function. Applied Soil Ecology 6, pp.3-16. 
[26] Gough, L., C.W. Osenberg, K.L. Gross, S.L. Collins, 2000. Fertilization effects on species density and primary productivity in herbaceous plant communities. OIKOS 89, pp.428-439.

[27] Graham, P.H., C.P. Vance, 2003. Legumes: Importance and Constraints to Greater Use. Plant Physiology March 131(3), pp.872-877. doi: http://dx.doi.org/10.1104/pp.017004.

[28] Gregory, P.J., J.S.I. Ingram, R. Andersson, R.A. Betts, V. Brovkin, T.N. Chase, P.R. Grace, A.J. Gray, N. Hamilton, T.B. Hardy, S.M. Howden, A. Jenkins, M. Meybeck, M. Olsson, I. Ortiz-Monasterio, C.A. Palm, T.W. Payn, M. Rummukainen, R.E. Schulze, M. Thiem, C. Valentin, M.J. Wilkinson, 2002. Environmental consequences of alternative practices for intensifying crop production. Agriculture, Ecosystems \& Environment 88(3), pp.279-290.

[29] Grinsven, H.J.M.van., H.F.M. ten Berge, T. Dalgaard, B. Fraters, P. Durand, A. Hart, G. Hofman, B.H. Jacobsen, S.T.J, Lalor, J.P. Lesschen, B. Osterburg, K.G. Richards, A-K. Techen, F. Vert'es, J. Webb, W.J. Willems, 2012. Management, regulation and environmental impacts of nitrogen fertilization in northwestern Europe under the Nitrates Directive; a benchmark study. Biogeosciences 9, pp.5143-5160. www.biogeosciences.net/9/5143/2012/ doi:10.5194/bg-9-51432012.

[30] Gruhn, P., F. Goletti, M. Yudelman, 2000. Integrated Nutrient Management, Soil Fertility, and Sustainable Agriculture: Current Issues and Future Challenges. Food, Agriculture, and the Environment Discussion Paper 32. International Food Policy Research Institute Washington.

[31] Haferkamp, M.R., 1988. Environmental factors affecting plant productivity, in White, R.S. and Short, R.E (Eds.), Achieving Efficient use of Rangeland Resources. Forth Keogh Reseacrh Symposium September 1987. Nontana Agr. Exp. Sta. Bozeman.

[32] Hall W.L.Jr., W.P. Robarge (Eds.), (2004) Environmental Impact of Fertilizer on Soil and Water, American Chemical Society ACS Symposium Series.

[33] Hanafiah, K.A., 2007. Dasar-Dasar Ilmu Tanah. Raja Grafindo Persada, Jakarta.

[34] Harper, L.A., V.R. Catchpoole, R. Davis, K.L. Weir, 1983. Ammonia Volatilization: Soil, Plant, and Microclimate Effects on Diurnal and Seasonal Fluctuations. Agronomy Journal 75(2), pp.212-218. doi:10.2134/agronj1983.00021962007500020014x.

[35] Hirel, B., J.L. Gouis, B. Ney, A. Gallais, 2007. The challenge of improving nitrogen use efficiency in crop plants: towards a more central role for genetic variability and quantitative genetics within integrated approaches. Journal of Experimental Botany 58(9), pp. 2369-2387. doi: 10.1093/jxb/erm097.

[36] Jarvis, S.C., B.F. Pain, 1990. Ammonia volatilization from agricultural land. Proceedings - Fertilizer Society 298 pp. 35-45.

[37] [KNLH] Kementerian Negara Lingkungan Hidup, 2010. Status Lingkungan Hidup Indonesia. Kementerian Lingkungan Hidup, Jakarta.

[38] Ladha, J.K., H. Pathak, T.J. Krupnik, J. Six, C. van Kessel, 2005. Efficiency of Fertilizer Nitrogen in Cereal Production: Retrospects and Prospects. Advances in Agronomy 87, pp.85156.

[39] Lea, P.J., R.A. Azevedo, 2006. Nitrogen use efficiency. 1. Uptake of nitrogen from the soil. Annals of Applied Biology 149(3), pp.243-247.

[40] Lee, F.A.,1975. Basic Food Chemistry. AVI Publishing, Westport, Connecticut.

[41] Lin, B.B., I. Perfecto, J. Vandermeer, 2008. Synergies between Agricultural Intensification and Climate Change Could Create Surprising Vulnerabilities for Crops. BioScience 58(9), pp.847854. doi: http://dx.doi.org/10.1641/B580911

[42] Lin, D.X., X.H. Fan, F. Hu, H.T. Zhao, J.F. Luo, 2007. Ammonia Volatilization and Nitrogen Utilisation Efficiency in Response to Urea Application in Rice Fields of the Taihu Lake Region, Chin. Pedosphere 17(5), pp.639-645.

[43] Moller, H., C.J. MacLeod, J. Haggerty, C. Rosin, G. Blackwell, C. Perley, S. Meadows, F. Weller, M. Gradwohl, 2008. Intensification of New Zealand agriculture: Implications for biodiversity. New Zealand Journal of Agricultural Research 51(3), pp.253-263.

[44] Mulyadi, N. Sutrisno, 2007. Pencemaran lingkungan pada lahan pertanian dan teknologi penanggulangannya. Prosiding Seminar Nasional Pertanian Lahan Rawa 3-4 Agustus 2007. Balai Penelitian dan Pengembangan Pertanian. Kapuas. Kalimantan Tengah.

[45] Mulvaney, R.L., S.A. Khan, C.S. Mulvaney, 1997. Nitrogen fertilizers promote denitrification. Biology and Fertility of Soils 24(2), pp.211-220.

[46] Othman, F. M. Sholichin, 2008. Predicting impact of fertilizer usage on water quality, Sutami reservoir, Indonesia. Journal of Environmental Hydrology 16 (paper 22). http://www.hydroweb.com

[47] Peoples, M.B., D.F. Herridge, J.K. Ladha, 1995. Biological nitrogen fixation: An efficient source of nitrogen for sustainable agricultural production? Plant and Soil 174(1-2), pp.3-28.

[48] Rasul, G., G.B. Thapa, 2003. Shifting cultivation in the mountains of South and Southeast Asia: Regional patterns and factors influencing the change. Land Degradation Development.14, pp.495-508.

[49] Raun, W.R., G.V. Johnson, 1999. Improving Nitrogen Use Efficiency for Cereal Production. Agronomy Journal. 91(3), pp.357-363.

[50] Ribaudo, M., J. Delgado, LeRoy. Hansen, M. Livingston, R. Mosheim, J. Williamson, 2011. Nitrogen in Agricultural Systems: Implications for Conservation Policy. A Report from the Economic Research Service United States Department of Agriculture. www.ers.usda.gov.

[51] Savci, S., 2012. An Agricultural Pollutant: Chemical Fertilizer. International Journal of Environmental Science and Development 3(1), pp.77-80.

[52] Schlegel, A.J., K.C. Dhuyvetter, J.L. Havlin, 1996. Economic and Environmental Impacts of Long-Term Nitrogen and Phosphorus Fertilization. Journal of Production Agriculture (9), pp.114-118.

[53] Sehy, U. R. Ruser, J.C. Munch, 2003. Nitrous oxide fluxes from maize fields: relationship to yield, site-specific fertilization, and soil conditions. Agriculture, Ecosystems \& Environment 99(13), pp.97-111.

[54] Setyorini, D. T., Prihatini, U. Kurnia, 2005. Pollution of Soil by Agricultural and Industrial Waste. Centre for Soil and Agroclimate Research and Development, Bogor Indonesia.

[55] Shriar, A.J., 2000. Agricultural intensity and its measurement in frontier regions. Agroforestry Systems 49(3), pp.301-318.

[56] Simanungkalit, R.D.M., D.A. Suriadikarta, R. Saraswati, D. Setyorini, W. Hartatik, 2006. Pupuk organik dan pupuk hayati. Balai Penelitian dan Pengembangan Pertanian. Bogor.

[57] Snyder, C.S., T.W. Bruulsem, T.L. Jensen, P.E. Fixen, 2009. Review of greenhouse gas emissions from crop production systems and fertilizer management effects. Agriculture, Ecosystems \& Environment 133(3-4), pp.247-266.

[58] Soemarsono, 2008. Nitrogen dan belerang tanah. www.scribd.com/doc/40630836/Nitrogen-Tanah [24 November 2011].

[59] Stoate, C., N.D. Boatman, R.J. Borralho, C.R. Carvalho, G.R.de. Snoo, P. Eden, 2001. Ecological impacts of arable intensification in Europe. Journal of Environmental Management 63, pp.337365.

[60] Suciati, L.P., B. Juanda, A. Fauzi, E. Rustiadi, 2014. Developing for Water Resources Incentives to Support System of Rice Intensification (SRI) in Jatiluhur Irrigation Area. IOSR Journal of Humanities and Social Science (IOSR -JHSS) 19(11), pp.3141.

[61] Sudaryanto, T., I.W. Rusastra, 2006. Kebijakan Strategis Usaha Pertanian Dalam Rangka Peningkatan Produksi dan Pengentasan Kemiskinan. Jurnal Litbang Pertanian 25(4), pp.115-122.

[62] Suganda, H., U. Kurnia, 2005. Optimalisasi pemanfaatan lahan rawa lebak dalam rangka pengembangan padi. Makalah pada Seminar Nasional Inovasi Teknologi Pengelolaan Sumberdaya Lahan Rawa dan Pengendalian Pencemaran Lingkungan, Banjarbaru 5-7 Oktober 2004, Kalimantan Selatan. 
[63] Sugiyanta. 2007. Peran Jerami dan Pupuk Hijau Terhadap Efisiensi dan Kecukupan Hara Lima Varietas Padi Sawah. Dissertasi. Bogor Agricultural University, Bogor Indonesia.

[64] Sukria, H.A. and Rantan. 2009. Sumber dan Ketersediaan Bahan Baku Pakan di Indonesia. IPB Press. Bogor.

[65] Supriadi, H., Rizal, A., Ismail, I.G. and Surachmat. 1986. Sumbangan pupuk hijau sebagai sumber nitrogen pada pertumbuhan padi sawah. Paper presented at the Seminar on Food Crops Research, Bogor 17-18 Desember 1986. Food Crops Research and Development Center, Bogor Indonesia.

[66] Sutanto, R., 2002. Penerapan Pertanian Organik: Pemasyarakatan dan Pengembangannya. Kanisius, Yogyakarta.

[67] Taslim, H., S. Partohardjono, Subandi, 1988. Pemupukan padi sawah in Padi Buku 2. Food Crops Research and Development Center, Bogor Indonesia.

[68] Tilman, D., 1999. Global environmental impacts of agricultural expansion: The need for sustainable and efficient practices. Proceedings of the National Academy of Sciences of the United States of America 96, pp. 115995-6000. doi: 10.1073/pnas.96.11.5995

[69] Tilman, D., C. Balzer, J. Hill, B.L. Befort, 2011. Global food demand and the sustainable intensification of agriculture. Proceedings of the National Academy of Sciences of the United States of America 108(50), pp.20260-20264

[70] Tscharntke, T., Y. Clough, T.C. Wanger, L. Jackson, I. Motzke, I. Perfecto, J. Vandermeer, A. Whitbread, 2012. Global food security, biodiversity conservation and the future of agricultural intensification. Biological Conservation 151(1), pp.53-59.

[71] Udiyani, P.M., M.B. Setiawan, 2003. Kajian Terhadap Pencemaran Lingkungan di Daerah Pertanian Berdasarkan Data Radioaktivitas Alam. Seminar Tahunan Pengawas Pemanfaan Tenaga Nuklir, Jakarta, Desember 2003.

[72] Ventere, R.T., M. Burgera, K.A. Spokas, 2005. Nitrogen Oxide and Methane Emissions under Varying Tillage and Fertilizer Management. Journal of Environmental Quality 34(5), pp.14671477. doi:10.2134/jeq2005.0018

[73] Vlek, P.L.G., B.H. Byrnes, 1986. The efficacy and loss of fertilizer $\mathrm{N}$ in lowland rice. Fertilizer Research 9(1-2), pp.131147.

[74] Wahid, A.S., 2003. Peningkatan Efisiensi Pupuk Nitrogen Pada Padi Sawah Dengan Metode Bagan Warna Daun. Jurnal Litbang Pertanian 4(22), pp.156-161.

[75] Wiramiharja, Y., R. Hernawati, I.M. Harahap, Y. Niwa, 2005. Nutrisi dan Bahan Pakan Ikan Budidaya Muaro, Jambi Indonesia. 